\title{
Analysis of the Demand for Eggs in City Of Malang
}

\author{
Nanang Febrianto ${ }^{1}$, Budi Hartono ${ }^{2}$, Dan Hari Dwi Utami ${ }^{2}$ \\ Faculty of Animal Husbandry Sciences, Brawijaya University, Malang, East Java, Indonesia
}

\begin{abstract}
This research was aimed at determining the factors that influence the demand for eggs in the City of Malang and knowing the elasticity of demand in relation to the changes in price of the eggs in the City of Malang. Data collection was conducted from November 2012 to December 2012 from the consumers who purchase eggs at the traditional markets in the City of Malang (Dinoyo market and Pasar Besar market). The research method being employed in this study was a survey method. Sampling was conducted through purposive sampling method. The data collected included the primary data from 200 respondents through direct observations and interviews and the secondary data that were obtained from certain relevant agencies. Data were then analyzed by using multiple linear regressions in logarithms. Regression analysis result showed that the independent variables together significantly affected $(P<0.01)$ the dependent variable with a value of $R^{2}$ was 0.731 . Partially that each of the prices of the eggs, household income, the family members, and education, affected the demand for eggs in the City of Malang. The price elasticity of demand for eggs is elastic with a value of -2.824. The value of the income elasticity of demand for eggs was 0.022 which was inelastic, which means that eggs are normal goods or commodity. The value of cross-price elasticity of demand for eggs to broiler meat was -4.451, which means that the broiler meat are not as substitutes (commodity) for eggs of egglaying chickens.
\end{abstract}

Keywords : eggs, demand, elasticity of the prices, elasticity of the demands

\section{INTRODUCTION}

The livestock sector in general has had progress; this can be identified by the presence of the livestock development for which is with shared responsibility between government, public and private. Government have conducted such organization, regulation, guidance, control as well as supervision to the availability of sufficient livestock products, antity and quality, safety, nutritious and evenly. Private and the public have the opportunity to play the widest in achieving adequacy farm products, include an executive production, trade and distribution of livestock products.

The prospect of layer farms or industries in Indonesia is considered excellent based on both the domestic and international market, when it is considered from in terms of supply and demand of the industry. On the supply apect, the production capacity of layer farms in Indonesia has yet to reach the real production capacity (Abidin, 2003). Such conditions can be seen from the increasing breeding companies, animal feed, and drugs that are still producing below installed capacity, it is as indication that the development prospect is still open. As it is seen from the aspect of demand, the current production of new sufficient eggs domestic markets needs by $65 \%$, the rest demand is dominated by the chicken eggs (native chickens), duck, and even quail.

The data for egg consumption in Indonesian population in 2009 was $5,827 \mathrm{~kg} /$ capita / year and $13.24 \%$ increase as it was compared to the year 2010 that amounted to $6,709 \mathrm{~kg} /$ capita / year. In terms of the egg production nationally showed that egg production is still fluctuating. In 2007 production amounted to 944,136 tons, in 2008 amounted to 955,999 tons, in 2009 amounted to 909,519 tons, 945,635 tonnes in 2010 and in 2011 the production of eggs amounted to 986,794 tons (Directorate General of Animal Husbandry Services, 2011). One factor to the increase in consumption of eggs is because they are relatively cheap compared to other livestock products, and they are easily available (on the market) and easy to process into various foods so that the egg is always considered as important need or commodity by many consumers.

Statistics showed that egg production in the City of Malang from 2006 to 2010 has decreased. The highest egg production was in 2006 amounted to $48,307 \mathrm{~kg}$ / year and the lowest was in 2010, amounted 38,180 $\mathrm{kg}$ / year, while the egg production in 2007 amounted to $43,053 \mathrm{~kg} /$ year in 2008 amounted to 47,306 kg / year and in 2009 amounted to 38,347 kg / year (Statistics Center of Malang, 2011), it is because the number of farms and farm land converted to settlements. The Animal Husbandry Department have been conducting such continuous efforts to increase production to meet the consumption besides eggs good for industry and for households, in addition it is also aimed to increase the income and employment opportunities. The efforts to increase egg consumption also have been conducted in order to achieve the protein consumption targets that have been determined, which means that as the egg consumption increases, it is also increasing the demand for eggs.

The other factors in relation to the increasing population, rising levels of education and household income also affect the level of the demands for eggs, this condition is necessary to predict the demand for eggs 
in the City of Malang. On the other hand, high population density as well as the rapid population growth led into such condition in the City of Malang where the land is now intended for residential development, while on the other hand the agricultural land is only a small part. Based on the things stated above, it is necessary to conduct research on the demand for eggs in the City of Malang. This study was aimed at 1) determining the factors that might influence the demand for eggs in the City of Malang; 2) determining the elasticity of the demand for eggs to the changes in price of eggs in the City of Malang.

\section{MATERIAL AND METHOD}

The research method employed in this study was a survey method (Sugiyono, 2011). In determining the location was done purposively, by the reason the Pasar Besar and Dinoyo markets are located in the center of the city and have the highest population density which amounted up to 11.99 and 8.23 (Statistics Center of Malang, 201 1). Sampling was done by purposive sampling method with some considerations of 1) buying eggs for a family (household needs) and 2) for their own consumption. The data collection was conducted from November to December 2012. The primary data was collected through observations and interviews through the instrument in the form of a questionnaire that includes a profile of respondents, the reason for choosing the number of eggs and the demand for eggs required each respondent in every month, the price of eggs, the price of native chicken eggs, the price of broiler meat, and the price of rice and catfish prices. Secondary data was derived from the statistics belonging to the Department of Animal Husbandry, Statistics Center of Malang and other related data as the supplementary sources.

The function for the demand for eggs was estimated using linear regression analysis in logarithms (Gujarati, 1999). Mathematically the function for thid demand is formulated as follows:

$\ln \mathrm{y}=\ln \alpha+b_{1} \ln \mathrm{X}_{1}+\mathrm{b}_{2} \ln \mathrm{X}_{2}+\mathrm{b}_{3} \ln \mathrm{X}_{3}+\mathrm{b}_{4} \ln \mathrm{X}_{4}+\mathrm{b}_{5} \ln \mathrm{X}_{5}+\mathrm{b}_{6} \ln \mathrm{X}_{6}+\mathrm{b}_{7} \ln \mathrm{X}_{7}+\mathrm{b}_{8} \ln \mathrm{X}_{8}+\mathrm{b}_{9} \ln \mathrm{X}_{9}+\mathrm{b}_{10} \ln$

$\mathrm{X}_{10}+\mathrm{b}_{11} \ln \mathrm{X}_{11}+\mathrm{b}_{12} \ln \mathrm{X}_{12}+\mathrm{u} \ln \mathrm{e}$

Caption:

$\mathrm{Y}=$ the demand for eggs ( $\mathrm{kg} / \mathrm{month})$

$\mathrm{X}_{1}=$ the price of layer eggs $(\mathrm{Rp} / \mathrm{kg})$

$\mathrm{X}_{2}=$ the price of native chicken eggs $(\mathrm{Rp} / \mathrm{kg})$

$\mathrm{X}_{3}=$ the price of broiler $(\mathrm{Rp} / \mathrm{kg})$

$\mathrm{X}_{4}=$ the price of catfish $(\mathrm{Rp} / \mathrm{kg})$

$\mathrm{X}_{5}=$ the price of rice $(\mathrm{Rp} / \mathrm{kg})$

$\mathrm{X}_{6}=$ the price of cooking oil $(\mathrm{Rp} / \mathrm{kg})$

$\mathrm{X}_{7}=$ household income $(\mathrm{Rp})$

$\mathrm{X}_{8}=$ the number of household members (people)

$\mathrm{X}_{9}=$ age

$\mathrm{X}_{10}=$ education

$\mathrm{X}_{11}=$ gender $/ \mathrm{sex}$

$\mathrm{X}_{12}=$ taste $($ on kind of food)

$\mathrm{a}=$ constant

$\mathrm{b}=$ regression coefficient

$\mathrm{e}=$ errors (disturbance term)

Data were analyzed through multiple linear regression models later in the anti-ln-right to get the value of the elasticity of the demand for eggs (Soekartawi, 1994).

\section{1) Analysis of the demand for eggs}

\section{RESULTS AND DISCUSSION}

Based on the results of multiple linear regression analysis of the independent variables tested (the price of layer eggs, the price of native chicken eggs, the broiler, the price of catfish, the price of rice, the price of cooking oil, household income, the number of household members, age, education, gender and taste), they have effects to the dependent variable (the demand for eggs).

Based on the results of the analysis obtained in table, the F-count value was 51.086 and the value was greater than the F-table value (7.720). This means that the effect of the independent variables together to demand for eggs significant at $5 \%$ level of confidence. On the other hand, the value of $\mathrm{R}^{2}$ was 0.731 . This value indicates that $73.1 \%$ variation dependent variable (the demand for eggs in Malang) can be explained jointly by the independent variables in this study, while the remaining $26.9 \%$ is explained by other variables which are not examined in this study. 


\section{2) The price of the eggs}

The prices in the study showed the value of buying eggs by the respondents for each kilogram of the eggs. The result from regression analysis showed variable rates eggs showed a significant effect and had a negative relationship with demand for eggs in the City of Malang. The value of the regression coefficient of the variable (the price of the eggs) was at -2.824 . It means that if the price of eggs increased by $1 \%$, while other factors held constant, the demand for eggs in the city of Malang will decline by $2,824 \%$.

Price variable eggs themselves follow the law of demand that is if the price of eggs rises, the demand for eggs has decreased and vice versa. This is in line with the opinions Lipsey, et.al (1995) that the decline in the price of a commodity complementary will also lead to more commodities to be bought at any price level whereas substitution commodity price increases will lead to more specific commodities to be bought at every level price.

Arsyad (2008) states that the price is variable that occasionally infuences the consumers into whether buying a product because of the price itself is associated with a person's ability to buy an item and also the price should run parallel with the quality of the product as well that if the product quality is good then consumers are willing to pay higher for the product.

Hadini, et.al (2011) added the results of his research that the rise in prices of other goods will lead the buyers to look for other goods that can be used as a substitute to the goods that the price increases. Conversely, if prices fall then people reduce purchases of other goods of the same type (substitute) and add to the purchase the goods that decrease in price. These research findings are consistent with the findings of Wahyuningsih, et.al (2008) that the price of chicken eggs in all three groups of consumers shows significant influence obviously and have a negative correlation to the demand of chicken eggs in East Java.

\section{3) Household income}

The result of the regression analysis in the table shows that the variable of household income has significant effect positively in relation to the amount of demand for eggs in the City of Malang. Income variable regression coefficient is 0.022 . The figure shows that if the household income increases by $1 \%$ and the other factors held constant, the demand for eggs would increase by $0,022 \%$. This result is in line with the findings Wahyuningsih, et.al (2008) which also describes the variable household income significantly affects the demand for chicken eggs in East Java. The increase of household income will lead into the more demand for the commodity at any price level. The result was also confirmed by Setiawan, et.al (2006) that family income will determine purchasing power to certain commodity, higher-income consumers will have greater buying power as the ability to purchase any goods also increases.

\section{4) The number of household members}

The coefficient of the variable of the number of household or family members showed a significant effect and had a positive relationship with the demand for eggs. The magnitude of the effect of family size was indicated by the regression coefficient of 0.744 . This means that if the number of family members increases one person, while the variables are held constant, the demand for eggs in the City of Malang will increase by $0.744 \%$ per month.

The results according to the statement from Soekartawi (2002) that the number of family members affects the consumption of the purchasing goods. The larger the number of family members, the more the number of items that should be available, the faster spending to the products being purchased and required as supplies in the household. The statement was strengthened by the results of Wahyuningsih, et.al (2008) study that in East Java, the number of family members is also has a positive effect to the demand for chicken eggs. The changes on the number of the people will affect the quantity of the demands for certain goods.

\section{5) Education}

The analysis showed the variable of the levels of education has a significant influence on the demand for eggs. Education variable has a regression coefficient of 0.060 . This means that the higher the education level of the respondents, while other variables are held constant, the demand for eggs in Malang will increase by $0.060 \%$ per month.

This is consistent with Suryanto, et.al research (2008) that the higher the level of education the more the understanding that can be taken by a consumer to the product. Simamora's revelation (2008) was to strengthen the influence of the level of educational to the demand, the higher the level of education a person will be more selective in choosing the product that they will consume.

\section{6) Elasticity of the demand for the eggs}

The magnitude of the effect of such factor can be determined through the demand elasticity of the demand for eggs which consists of the price elasticity, the income elasticity and the cross-price elasticity 
(Soekartawi, 2002). Furthermore, in order to determine consumer response to the factors that influence the demand for eggs, it can be explained as follows:

\section{7) The price elasticity}

The demand function models used indicated that the magnitude of the regression coefficient was the value of the price elasticity of the eggs, the magnitude of price elasticity (Eh) is $-2,824$. This number can be asserted that if the price of the eggs increases $1 \%$, the demand for eggs would decline by $2,824 \%$. The decrease in the demand when prices rise indicates the occurranc of the law of demand to the demand for eggs. Furthermore it can be said that the nature of the eggs as commodity is elastic because the numbers obtained larger one (1) or $\mathrm{Eh}<-1$.

The research result was in line with Wahyuningsih, et.al (2008) as it is mentioned that the price elasticity is -2.21 for the combined strata, -1.67 for above strata and $-7,3$ for the lower classes in the countryside and cities in East Java. The results of a study that was obtained by Irawan (1992) shows the value of the price elasticity for eggs at all income strata in rural and Javanese-Balinese towns is within -1.84 to -2.99 , indicating that the demand for eggs in East Java until 2008 still is elastic. According Sukirno, (2005) that the price elasticity of the demand will always be negative, this is because the price and quantity of goods demanded changes in opposite direction.

\section{The income elasticity}

The value of the income elasticity is 0.022 , which means the elasticity is inelastic, in other words that every $1 \%$ increase in the amount of household income will lead to increased demand for eggs by $0.022 \%$. The value of the income elasticity suggests that the City of Malang has increased the standard of living so the tendency of goods consumption toward usability of the goods higher than eggs, so if there is an increase in household income Malang society will lead to increase the demand for chicken eggs in the City of Malang. Based on the elasticity values obtained, it can be concluded that the eggs in the city is normal commodity as the value of the income elasticity $(\mathrm{Ei})$ is positive or between zero and one $(0<\mathrm{Ei}<1)$.

This is in accordance to Tomek opinion, et.al (1998) who says that the revenue and demand has a positive relationship, which means that the more the income, the more the demand (Ceteris paribus). Added by Wahyuningsih, et.al (2008) in her study on the demand for eggs in East Java showed that the income elasticity of 0.23 and it is concluded that in eggs in East Java is categorized into the normal commodity as the income elasticity is positive. The results Maruli (1994) in Jambi also showed that chicken eggs are normal goods with an income elasticity of 0.38 varies according to income strata. The results above reinforce sufficiently by the research of Utami, (1998) which shows that in Indonesia, the eggs are normal goods; obtained an income elasticity of 0.11 varies by location and income strata.

\section{8) The cross-price elasticity}

The cross-price elasticity compares between the changes in the volume of the demand for offered goods by the changes in prices of the other goods. The value of the cross-price elasticity of the demand for eggs for broiler meat is equal to -4.451 , which indicates that broiler meat cannot be used as substitute for eggs because the elasticity is negative and broiler meat prices of variable factors that result is not significant to the demand for eggs chicken in the City of Malang. This condition may cause the value of elasticity cannot be used for broiler meat or it is not as substitute goods or goods that can replace the usefulness of eggs in the city of Malang, so that when the price of eggs increases, the broiler meat cannot replace the eggs. This can happen because the people who have sufficient income in Malang are high, causing more people have the ability to choose the product that they will consume.

These results are in line with the research by Suryanto, et.al (2008) that despite using contradictory commodity leads into the cross-price elasticity the demand for broiler meat to eggs to householders in Tangerang is negative so that the eggs cannot substitute broiler meat. The result of the research when it is connected with the explanation Muslich, (2003) that the cross-price elasticity is the ratio between the changes in the volume of demand of offered goods with price changes of the other goods. The other goods are similar goods that have the same utility function being sold by competitors (substitutes) or other goods that are complementary (complementary). The theory does not apply because the existence of broiler meat cannot replace the use of eggs when the price rises. 
TABLE 1. THE RESULT OF THE REGRESSION ANALYSIS TO THE DEMAND FOR EGGS FUNCTION IN THE CITY OF MALANG

\begin{tabular}{lrrr}
\hline \multicolumn{1}{c}{ Independent variables } & $\begin{array}{l}\text { Regression } \\
\text { coefficient }\end{array}$ & t-count & Sig \\
\hline Constant & 270.281 & -0.848 & 0.397 \\
The price of the eggs (layer eggs) $\left(\mathrm{X}_{1}\right)$ & $-2.824^{*}$ & 2.001 & 0.047 \\
The price of the eggs (native chicken) $\left(\mathrm{X}_{2}\right)$ & 8.098 & 0.365 & 0.716 \\
The price of broiler $\left(\mathrm{X}_{3}\right)$ & -4.451 & -0.212 & 0.832 \\
The price of catfish $\left(\mathrm{X}_{4}\right)$ & -0.575 & -0.040 & 0.968 \\
The price of rice $\left(\mathrm{X}_{5}\right)$ & 18.840 & 1.277 & 0.203 \\
The price of cooking oil $\left(\mathrm{X}_{6}\right)$ & 4.598 & 0.563 & 0.574 \\
Household income $\left(\mathrm{X}_{7}\right)$ & $0.022^{*}$ & 2.027 & 0.043 \\
The number of family members $\left(\mathrm{X}_{8}\right)$ & $0.744 * *$ & 35.261 & 0.000 \\
Age $\left(\mathrm{X}_{9}\right)$ & 0.285 & 0.913 & 0.362 \\
Education $\left(\mathrm{X}_{10}\right)$ & $0.060^{*}$ & -2.216 & 0.028 \\
Sex / gender $\left(\mathrm{X}_{11}\right)$ & 0.056 & 0.466 & 0.672 \\
Taste $\left(\mathrm{X}_{12}\right)$ & -0.008 & -0.133 & 0.894 \\
\hline Determination coefficient $\left(\mathrm{R}^{2}\right)$ & 0.731 & & \\
F-count & 51.086 & & \\
\hline Note: & & & \\
\hline
\end{tabular}

\begin{tabular}{ll}
\hline Note: & \\
$*$ & : significant at $95 \%$ confidence level \\
$* *$ & : significant at the $99 \%$ confidence level.
\end{tabular}

\section{CONCLUSION}

The price of the eggs negatively affects the demand for eggs themselves. On the other hand, the household income, the number of family members, education positively affects to the demand for eggs. The price elasticity of the demand for eggs in the city of Malang is elastic, while the income elasticity in the City of Malang for demand is inelastic.

\section{REFERENCES}

[1] Abidin, Z. 2003. Meningkatkan Produktivitas Ayam Ras Petelur. PT. Agromedia Pustaka. Jakarta.

[2] Arsyad, L. 2008. Ekonomi Manajerial: Ekonomi Mikro Terapan untuk Manajemen Bisnis. BPFE Yogyakarta. Yogyakarta.

[3] National Health and Nutrition Directorates. 1989. Daftar Komposisi Bahan Makanan. Bharata. Jakarta.

[4] Directorate General of Animal Husbandry. 2011. Statistik Peternakan dan Kesehatan Hewan. Directorate General of Animal Husbandry, Agriculture Department. Jakarta.

[5] Engel, J.F.R.D. Black Well. and P.W Miniard. 1995. Perilaku Konsumen. Binarupa Aksara. Jakarta.

[6] Gujarati, D. 1999. Ekonometrika Dasar 6 ${ }^{\text {th }}$ Edition. Erlangga. Jakarta.

[7] Hadini, H.A. Nurtini, S. Sulastri, E. 2011. Analisis Permintaan dan Prediksi Konsumsi serta Produksi Daging Broiler di Kota Kendari Propinsi Sulawesi Tenggara. Buletin Peternakan Volume 35 (3) : 202-207, Oktober 2011.

[8] Irawan, B. 1992. Pola Konsumsi Telur di Jawa Tengah. Laporan Hasil Penelitian Lembaga Penelitian. Universitas Jenderal Sudirman. Purwokerto.

[9] Lipsey, G.R. Steiner, P.O. dan Purvis, P.D. 1995. Pengantar Mikroekonomi. 10 ${ }^{\text {th }}$ Edition. Binarupa Aksara. Jakarta.Maruli, P. 1994. Analisis Permintaan Telur di Propinsi Jambi. Thesis. Universitas Gajah Mada.Yogyakarta.

[10] Muslich, 2003. Ekonomi Managerial: Alat Analisis Strategi dan Kebijaksanaan Bisnis. Ekonisia. Yogyakarta.

[11] Santoso, E.P. 2011. Perilaku Konsumen Dalam Keputusan Pembelian Ayam Goreng Cepat Saji (Fast Food) Di Kota Malang. Thesis, Universitas Brawijaya. Malang.

[12] Setiawan, B.M, Roessali, W. dan Asiyah, S.N. 2006. Analisis Permintaan Daging Ayam Pedaging Pada pasar Tradisional di Kecamatan Mranggen Kabupaten Demak. Universitas Diponegoro. Semarang.

[13] Soekartawi. 1994. Teori Ekonomi Produksi: dengan Pokok Bahasan Analisis Fungsi Cobb-Douglas. Raja Grafindo Persada. Jakarta.

[14] Soekartawi. 2002. Prinsip Dasar Ekonomi Pertanian Teori dan Aplikasi. Raja Grafindo Persada. Jakarta.

[15] Simamora, B. 2008. Panduan Riset Perilaku Konsumen. Gramedia Pustaka Utama. Jakarta

[16] Statistic Center of Malang. 2011. Malang

[17] Sugiyono. 2011. Statitistika untuk Penelitian. Alfabeta. Bandung

[18] Sukirno, S. 2005. Mikro Ekonomi: Teori Pengantar. Edisi ke-3. Jakarta: Raja Grafindo Persada.

[19] Suryanto, B. Mulyatno, B. Indriatie, F.D. 2008. Beberapa Faktor yang Mempengaruhi Permintaan Broiler pada Konsumen Rumah Tangga di Kecamatan Pamulang Kabupaten Tangerang. Journal Indon. Trop. Anim. Agric. 33 (1) March 2008.

[20] Tomek, W and Robinson, K 1998. Agricultural Product Price. Cornell University Press Ltd. New York.

[21] Utami, K.S. 1998. Permintaan Bahan Pangan Penting di Indonesia. Disertasi. Institut Pertanian Bogor. Bogor.

[22] Wahyuningsih, R. Kiptiyah, S.M. Semaoen, H.M.I. 2008. Analisis Permintaan Telur Ayam Di Jawa Timur (Analysis Of Demand For Chicken Egg At East Java). Jurnal Agritek Vol 16 No. 11. November 2008. 